\title{
Muscle Cell Enzyme Activities in Serum of Japanese Landrace Pigs and Their Relationship to the Physical Properties of Meat
}

\author{
Shozo Watanabe, Tomiji Akita, Hiroshi Nishojı*, Shigeru Ito*, \\ Akira Nishida* and Kentaro Himeno \\ National Institute of Animal Industry, Chiba-shi, 280 \\ * Iwate Prefectural Livestock Experiment Station, \\ Takizawa-mura, Iwate-ken, 020-01
}

(Received August 30, 1977)

\begin{abstract}
The activities of CPK, ALD and $\mathrm{LDH}_{\mathrm{t}}$, and $\mathrm{LDH}$ isozyme pattern in serum were determined in 76 growing and fattening Japanese Landrace pigs under resting condition. The experimental animals were bled for the muscle cell enzyme determination at the age of $139.7 \pm 10.5$ days and 61 pigs were slaughtered at $90 \mathrm{~kg}$ of body weight to obtain carcass characters and the physical properties of meat at the age of $150.8 \pm 10.2$ days. Ten animals having extremely high activities of $\mathrm{CPK}, \mathrm{ALD}$ and $\mathrm{LDH}_{\mathrm{t}}$, and similarly high percentage of $\mathrm{LDH}_{5}$ isozyme were recognized. Higher relative incidence of extremely disadvantageous values of water-holding capacity, toughness and Hunter's L value of meat was observed in such animals than in the animals of normal enzyme activities. Statistically significant but low correlation coefficients were reconfirmed between the activity of $\mathrm{CPK}$ and the percentage of $\mathrm{LDH}_{5}$, and water-holding capacity and toughness of meat. Also, such correlation coefficients were found between $\mathrm{LDH}_{\mathbf{t}}$ and $\mathrm{LDH}_{5}$, and a meat character index constructed by the standardized deviation of the three physical properties. The role of the muscle cell enzyme activities in serum of the resting animals was discussed as an indicator for detecting stress-susceptible pigs being prone to produce the meat of disadvantageous physical properties.
\end{abstract}

A considerable amount of efforts has been directed toward establishing the physio-genetic role of the muscle cell enzymes in serum of pigs as an indicator for stress-susceptibility and muscle properties recently ${ }^{1-4)}$. Methods for detecting stress-susceptible animals have been proposed by comparing the enzyme activities between resting and stressed conditions of animals ${ }^{5-32}$. And the stress-susceptible animals thus detected have been regarded as being prone to produce the meat of undesirable quality.

Following a shift of major pig breeds from the pork type to bacon or meat type observed in 1968, porcine stress syndrome and/or pale, soft and exudative pork problems have been attracting a keen attention in both pig producers and consumers in Japan. However, informations on the relationship between porcine stress-susceptibility and meat cuality are very scarce in Japan.

The purpose of the present study is to elucidate the distribution of the activities of creatine phosphokinase (CPK), aldolase (ALD) and lactate dehydrogenase $\left(\mathrm{LDH}_{\mathrm{t}}\right)$, and $\mathrm{LDH}$ isozyme pattern in the resting animals and to confirm the relationship between the activities of muscle cell Jap. J. Zootech. Sci., 49, (4): 283-294. 


\section{Watanabe, Akita, Nishoji, Ito, Nishida and Himeno}

enzymes in serum and the physical properties of meat in Japanese Landrace pigs as the first step toward the establishment of a practical screening method.

\section{Materials and Methods}

A total of 76 Landrace pigs kept in National Institute of Animal Industry and Iwate Prefectural Livestock Experiment Station were used in this study. Sixty-three pigs of Iwate Station were under progeny tests for the meat performance. The 63 pigs were bled at the age of 139.7 \pm 10.5 days in July, 1976 and slaughtered to obtain the carcass characters and the physical properties of meat when they reached the body weight of $90 \mathrm{~kg}$ at the age of $150.8 \pm 10.2$ days, except two pigs which were discarded during the test period. All the pigs of Iwate Station were bled from ear veins by nose-restaining. Thirteen pigs of National Institute were used for confirming the difference of enzymic activities in serum due to the methods of blood collection, i.e. bleeding from ear veins or Vena jugularis externa, or sampling from exsanguination during slaughter ${ }^{12,29)}$.

The sera were separated as quickly as possible after sample collection and frozen at $-20^{\circ} \mathrm{C}$. Within two weeks after the collection, the sera were thawed and the activities of CPK, ALD and $\mathrm{LDH}_{\mathrm{t}}$, and the isozyme pattern of LDH were determined. The determinations of the activities of $\mathrm{CPK}, \mathrm{ALD}$ and $\mathrm{LDH}_{\mathrm{t}}$ were carried out with U.V. Test kits supplied by Boehringer-Mannheim, West Germany, and Hitachi spectrophotometer model 101 was used. For the electrophoresis of sera to obtain zymograms of LDH isozymes, an agar gel plate of LDH Isozyme-Test kit, manufactured by Wako Pure Chemical Industries, Osaka, Japan was employed. The densitometry of the zymograms was carried out by AD 200 degital densitometer manufactured by Yamato Scientific Apparatus Company, Tokyo, Japan.

The samples of fresh meat for the determination of toughness, Hunter's $L$ value and waterholding capacity were taken from the 6-7th, 8 th and 9 th rib cut of $M$. longissimus dorsi, respectively, 48 hours after slaughter. Hunter's L value of meat was measured by TC-50 color difference meter, manufactured by Tokyo Denshoku Company, Japan. Toughness of meat was determined by Texturometer GTX 2 model, manufactured by General Foods, U.S. A. ${ }^{83}$ Water-holding capacity was determined by means of salting and heating of the ground meat and centrifugal separation of the liquic ${ }^{34,35)}$.

To describe the merit of meat objectively in relation to PSE condition, a meat character index ( $\operatorname{Im})$ proposed by MÄDER et al.26) was employed with a partial modification. The meat character index in the present study was given by the following formula.

$$
\operatorname{Im}=\frac{x-\bar{x}}{\sigma_{x}}-\frac{y-\bar{y}}{\sigma_{y}}-\frac{z-\bar{z}}{\sigma_{z}}
$$

where $x=$ Water-holding capacity, $\bar{x}=$ Mean of water-holding capacity, $\sigma_{x}=$ Standard deviation of water-holding capacity, $y=$ Toughness of meat, $\bar{y}=$ Mean of toughness of meat, $\sigma_{y}=$ Standard deviation of toughness of meat, $z=$ Hunter's $\mathrm{L}$ value, $\bar{z}=$ Mean of Hunter's $\mathrm{L}$ value. $\sigma_{z}=$ Standard deviation of Hunter's $L$ value.

The mean of this index is always zero. Therefore, positive or negative deviation of the meat character of the experimental animals is easily indicated with a sign in this index. The meat with a positive index was regarded as relatively advantageous and the meat with a negative index as relatively disadvantageous for preservation, and for organoleptic and technical properties.

For the statistical analysis, the values of $\mathrm{CPK}$ and $\mathrm{LDH}_{\mathrm{t}}$ activities were subjected to logarithmic transformation to obtain a normal distribution ${ }^{8,19,29,911}$. 


\section{Results}

Difference of the activities of the muscle cell enzymes in serum due to the methods of sample collection.

The difference of the enzyme activities in serum due to the methods of sample collection is shown in Table 1. The blood obtained from ear veins apparently showed the lowest values of the activities of $\mathrm{CPK}$ and $\mathrm{LDH}_{\mathrm{t}}$, and the percentage of $\mathrm{LDH}_{6}$ among the samples from ear veins, exsanguination and Vena iugvlaris externa, as reported by other workers ${ }^{12.29)}$.

Distribution of the activities of the muscle cell enzymes in serum and the physical properties of meat.

The results of enzyme determination in serum of 63 pigs of Iwate Station are shown in Figure 1. The activities of $\mathrm{CPK}$ and $\mathrm{LDH}_{\mathrm{t}}$ did not show normal distribution curves while ALD exhibited a normal one as reported by other workers ${ }^{8,19,29,32)}$. Individuals showing the extremely high activities of $\mathrm{CPK}, \mathrm{ALD}$ and $\mathrm{LDH}_{\mathrm{t}}$, and similary high percentage of $\mathrm{LDH}_{5}$ were observed as shown in Figure 1. And in fewer cases, the same trend as in $\mathrm{LDH}_{5}$ was recongnized in $\mathrm{LDH}_{4}$. Such values, making a set, were observed in a particular individual.

The values of the physical properties of meat obtained are shown in Figure 2. The individuals having extremely disadvantageous values which were predicted by enzyme determination are indicated in the histograms with identification numbers.

Relationship among the activities of the muscle cell enzymes in serum, the physical properties of meat and the meat character index.

In order to confirm the practical meaning of the activities of the muscle cell enzymes in serum, the individuals having the extremely disadvantageous Im values were picked up from the 61

Table 1. Difference of the activities of the muscle cell enzymes in serum due to sampling methods.

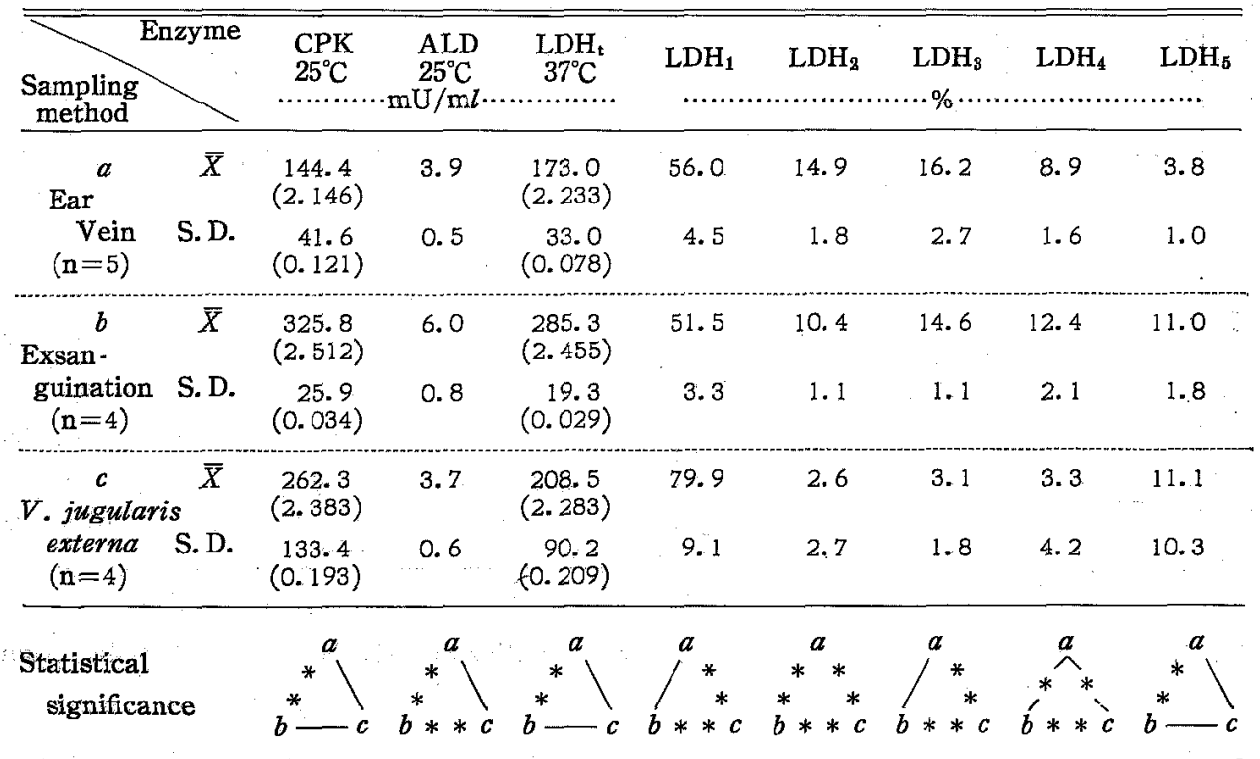

Figures in parentheses indicate logarithmic values. 

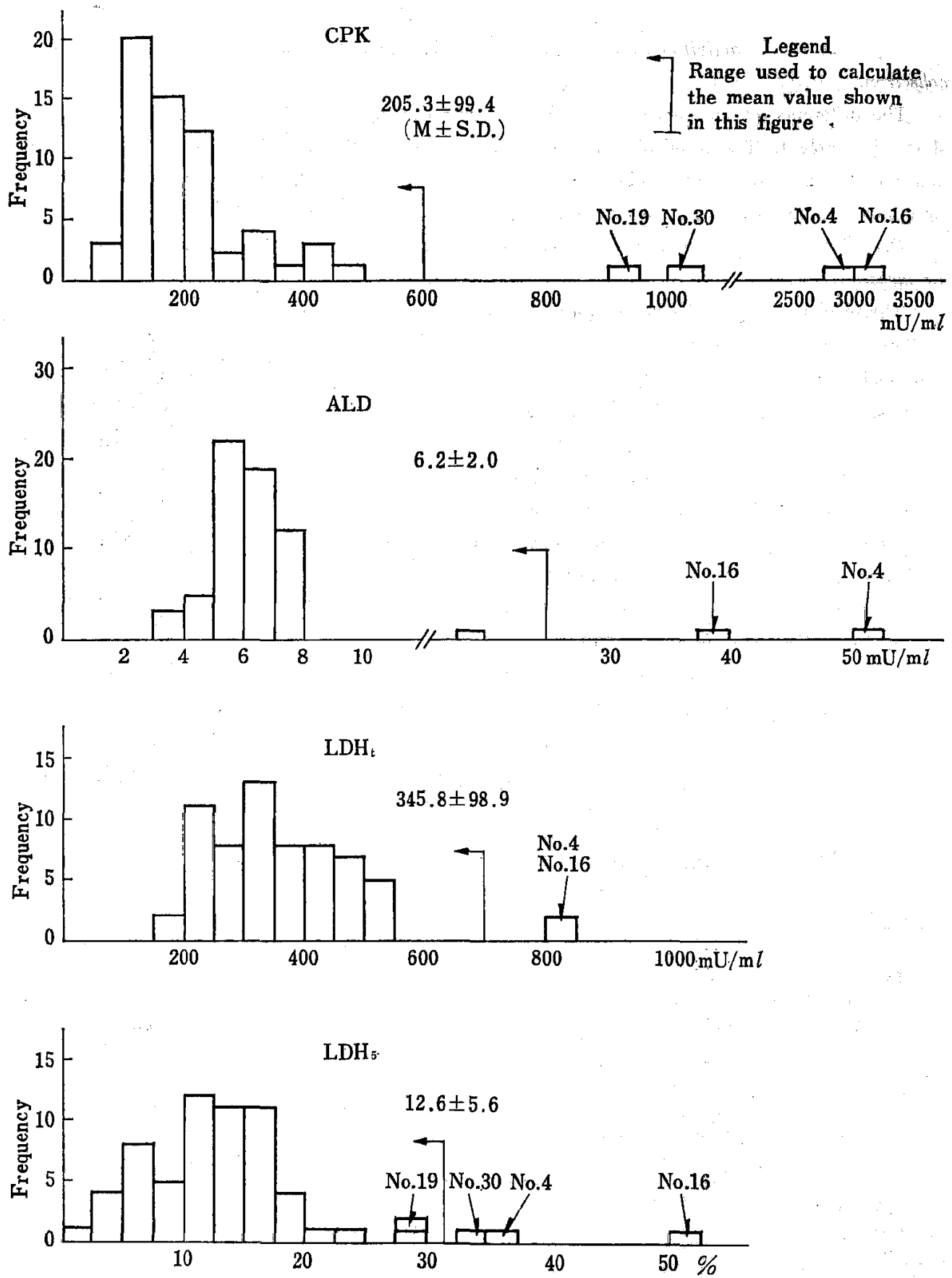

Fig. 1. Distribution of the muscle cell enzyme activities and the isozyme pattern in serum of Japanese Landrace pigs. 

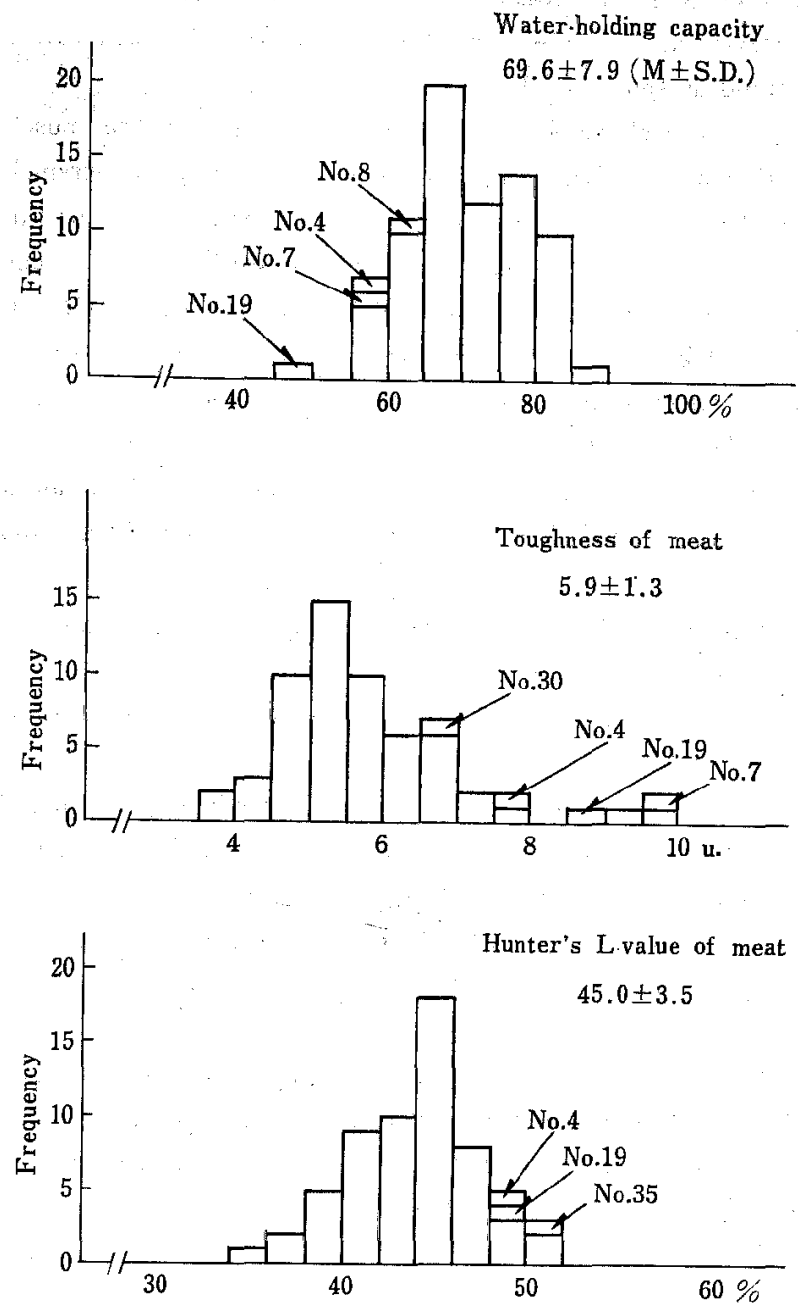

Fig. 2. Distribution of the physical properties of meat in Japanese Landrace pigs.

pigs of Iwate Station. The Im values varied from -6.18 to 4.68 in the 61 pigs. The range of an extremely disadvantageous value for Im was assumed less than -3.00 , which meant all the three physical properties deviated more than a standard deviation value from the mean of the population toward disadvantageous direction (or its equivalent in Im values).

Seven animals were picked up as having the extremely disadvantageous Im value (A). Fifteen animals were recongnized as having $\operatorname{Im}$ value below $-1.00(\mathrm{~B})$, and eight animals as having Im value below -2.00 (C). The comparison of the enzyme activities, the physical properties of meat and Im value between $\mathrm{A}$ group and the rest of the herdmates is shown in Table 2. Group A animals exhibited apparently higher values in CPK, ALD and LDH activities, and in the percentage of $\mathrm{LDH}_{5}$, than those of the other herdmates, though these differences were not statistically significant due to large variations. (The difference in $\mathrm{LDH}_{\mathrm{t}}$ was significant at $10 \%$ level of probability.) On the other hand, highly significant differences in the physical properties 
Watanabe, Akita, Nishoji, Ito, Nishiba and Himeno

were recognized between A group animals and the rest of herdmates. In this connection, the comparison of the enzyme activities between $B$ and $C$ groups, and each corresponding hermates exhibited the same trend as shown in Table 2.

For the second step to evaluate the significance of determining the muscle cell enzyme for the purpose of detecting animals being prone to produce the meat of extremely disadvantageous Im value, the animals having at least one value of the enzyme activities marking above two times the standard deviation limit from the population mean toward disadvantageous direction were picked up. Eleven animals were picked up from the 63 pigs as having such values. One of the eleven animals was culled before reaching the slaughter weight and so further calculations were made with ten animals. Of these ten animals as shown in Table 3, three had the extremely disadvantageous Im value below -3.00 . On the other hand, five animals out of ten had Im values below -1.00 and three out of the ten had Im values below -2.00 . Four animals (Pig Nos. 12, 25,28 and 35 ) of the seven animals having Im value below -3.00 did not show any particular patterns of enzymic activity.

Familial relationship among the muscle cell enzyme activities in serum, the physical properties of meat and Im values is shown in Table 3.

Correlation coefficients among the activities of the muscle cell enzymes in serum, the physical properties of meat and the meat character index.

Table 4 shows the correlation coefficients among the activities of the muscle cell enzymes in serum, the physical properties of meat and the meat character index. Highly significant correlation coefficients were found among the activities of $\mathrm{CPK}, \mathrm{ALD}, \mathrm{LDH}_{\mathfrak{t}}$ and the percentage of $\mathrm{LDH}_{5}$. Also, between $\mathrm{LDH}_{\mathrm{t}}$ and the percentage of $\mathrm{LDH}_{4}$, and $\mathrm{LDH}_{5}$, statistically significant correlations were recognized. Among the physical properties of meat, statistically significant and moderately high correlation coefficients were observed.

Between CPK activity and water-holding capacity, and toughness of meat, a correlation coefficient of $-0.271^{*}$ and $0.299 *$ was recognized, respectively. A correlation coefficient of $-0.345^{*}$ was observed between the percentage of $\mathrm{LDH}_{5}$ and water-holding capacity.

As to the relationship between the meat character index and the muscle cell enzymes in serum,

Table 2. Muscle cell enzyme activities in serum of pigs having the extremely disadvantageous values of the meat character index and the rest of herdmates.

\begin{tabular}{|c|c|c|c|c|c|c|c|c|c|c|c|c|c|}
\hline & & $\mathrm{CPK}$ & $\stackrel{\mathrm{ALD}}{\mathrm{mU} / \mathrm{m} l}$ & $\begin{array}{c}\mathrm{LDH}_{\mathrm{t}} \\
\cdots \cdots \cdots\end{array}$ & $\begin{array}{r}\mathrm{LDH}_{2} \\
\ldots . .\end{array}$ & $\mathrm{LDH}$ & ${ }_{2} \mathrm{LDH}$ & $\mathrm{LDH}$ & $\mathrm{I}_{4} \mathrm{LDH}_{5}$ & $\begin{array}{l}\text { W. H. } \\
\text { C. }(\%)\end{array}$ & T. M & I. L. & Im \\
\hline \multirow{2}{*}{$\begin{array}{l}\text { Extremely } \\
\text { djsadvanta- } \\
\text { geous grou } \\
(\mathrm{n}=7)\end{array}$} & $\bar{X}$ & $\begin{array}{l}675.6 \\
(2.56)\end{array}$ & 12.4 & $\begin{array}{c}436.0 \\
(2.62)\end{array}$ & 52.0 & 4.8 & 7.3 & 18.8 & 17.1 & $59.5^{\mathrm{a}}$ & $8.5^{\mathrm{a}}$ & $50.3^{\mathrm{a}}$ & $-4.83^{\mathrm{a}}$ \\
\hline & p S.D. & $\begin{array}{l}983.7 \\
(0.47)\end{array}$ & 16.7 & $\begin{array}{r}178.9 \\
(0.15)\end{array}$ & 10.8 & 1.9 & 1.9 & 8.4 & 10.7 & 5.6 & 1.2 & 1.5 & 1.04 \\
\hline \multirow{2}{*}{$\begin{array}{l}\text { The rest } \\
\text { of herd- } \\
\text { mates } \\
(n=54)\end{array}$} & $\bar{X}$ & $\begin{array}{r}214 . \\
(2.27\end{array}$ & 6.2 & $\begin{array}{l}348.8 \\
(2.53)\end{array}$ & 56.2 & 5.2 & 7.6 & 18.0 & 13.0 & $70.9^{b}$ & $5.6^{b}$ & $44.3^{b}$ & $0.66^{\mathrm{b}}$ \\
\hline & S.D. & $\begin{array}{c}145.9 \\
(0.22)\end{array}$ & 1.8 & $\begin{array}{r}98.0 \\
(0.12)\end{array}$ & 10.5 & 2.0 & 2.7 & 7.2 & 6.0 & 7.1 & 0.8 & 3.1 & 1.70 \\
\hline
\end{tabular}

W.H.C.: Water-holding capacity, T.M.: Toughness of meat expressed as $1.5 X$ Texturounit, L.: Hunter's L value. Figures in parentheses indicate logarithmic values. a, b: Means with different superscripts are significantly different $(P<0.01)$. \#: Means with these superscripts are significantly differrent $(\mathrm{P}<0.10)$. Im: The meat character index. 
Serum Muscle Enzymes and Physical Properties of Pork

Table 3. Relationship among the muscle cell enzyme activities in serum, the physical properties of meat and the meat character index.

\begin{tabular}{|c|c|c|c|c|c|c|c|c|c|c|c|c|}
\hline $\begin{array}{l}\text { Sire } \\
\text { No. }\end{array}$ & $\begin{array}{c}\text { Dam } \\
\text { No. }\end{array}$ & $\begin{array}{l}\text { Pig } \\
\text { No. }\end{array}$ & CPK & ALD & $\mathrm{LDH}_{\mathrm{t}}$ & $\mathrm{LDH}_{1}$ & $\mathrm{LDH}_{4}$ & $\mathrm{LDH}_{5}$ & W. H.C. & T.M. & L. & Im \\
\hline \multirow{2}{*}{1} & \multirow{2}{*}{2} & 3 & 289 & 6.5 & 321 & 64.1 & 13.4 & 13.9 & 66.36 & 7.08 & 42.2 & -0.53 \\
\hline & & 4 & $2824 *$ & $50.2^{*}$ & $810^{*}$ & 32.1 & 21.4 & $35.6 *$ & 60.37 & 7.64 & 50.4 & -4.08 \\
\hline \multirow{2}{*}{5} & \multirow{2}{*}{6} & 7 & 203 & 6.9 & 415 & 44.1 & $32.6^{*}$ & 11.0 & 59.96 & 9.91 & 47.8 & -5.19 \\
\hline & & 8 & 307 & 5.9 & 513 & 39.6 & $33.5 *$ & 5.7 & 61.70 & 6.74 & 45.8 & -1.88 \\
\hline \multirow{2}{*}{9} & \multirow{2}{*}{10} & 11 & 128 & 4.0 & 201 & 73.5 & 13.6 & 4.1 & 71.31 & 5.38 & 455 & 0. 51 \\
\hline & & 12 & 220 & 5.2 & 352 & 61.8 & 14.1 & 5.9 & 59.91 & 9.21 & 50.4 & -5.38 \\
\hline \multirow{4}{*}{13} & \multirow{2}{*}{14} & 15 & 173 & 6.0 & 464 & 44.1 & 23.9 & 16.8 & 70.89 & 4.48 & 48.8 & -0.10 \\
\hline & & 16 & $3299 *$ & $39.0^{*}$ & $810^{*}$ & $19.7 *$ & 20.3 & $50.2^{*}$ & - & - & - & - \\
\hline & \multirow[t]{2}{*}{17} & 18 & 401 & 7.0 & 428 & 64.5 & 10.4 & 10.1 & 74.63 & 4.69 & 38.3 & 3. 53 \\
\hline & & 19 & $908 *$ & 7.9 & 390 & 51.4 & 4.6 & $28.0^{*}$ & 49.29 & 8.80 & 49.6 & -6.18 \\
\hline & \multirow{2}{*}{21} & 22 & 130 & 7.4 & 285 & 54.0 & 19.1 & 18.5 & 58.14 & 5.37 & 47.8 & -1.82 \\
\hline & & 23 & 222 & $19.5^{*}$ & 424 & 49.4 & 14.4 & $29.9^{*}$ & 68.12 & 5.13 & 43. 7 & 0.81 \\
\hline & 24 & 25 & 186 & 6.8 & 485 & 54.4 & 20.8 & 15.2 & 63.71 & 9.57 & 51.5 & -5.50 \\
\hline \multirow[t]{4}{*}{20\{} & \multirow{2}{*}{26} & 27 & 129 & 5.7 & 360 & 52.5 & 29.8 & 7.0 & 68.66 & 4.75 & 45.9 & 0.56 \\
\hline & & 28 & 165 & 5.3 & 339 & 61.8 & 19.6 & 9.3 & 55.98 & 7.64 & 49.7 & -4.44 \\
\hline & \multirow{2}{*}{29} & 30 & $1008 *$ & 7.0 & 441 & 42.2 & 17.1 & $33.0^{*}$ & 69.27 & 7.08 & 45.3 & -1.04 \\
\hline & & 31 & 126 & 6.3 & 284 & 57.6 & 20.9 & 4.0 & 65.35 & 6.47 & 43.7 & -0.61 \\
\hline \multirow{2}{*}{32} & \multirow{2}{*}{33} & 34 & 107 & 6.7 & 366 & 54.8 & 21.8 & 11.5 & 76.71 & 6.99 & 45.8 & -0.17 \\
\hline & & 35 & 223 & 4.8 & 261 & 58.1 & 19.1 & 14.9 & 67.00 & 6.66 & 52.5 & -3.06 \\
\hline
\end{tabular}

W.H.C.: Water-holding capacity of meat, T.M.: Toughness of meat, L.: Hunter's L value, Im: The meat character index. * indicates values marking above twice the standard devia* tion limit from the population mean toward the disadvantageous direction.

Table 4. Correlation coefficients among the muscle cell enzyme activities in serum, the physical properties of meat and the meat character index.

\begin{tabular}{|c|c|c|c|c|c|c|c|c|c|}
\hline & CPK & $A L D$ & $\mathrm{LDH}_{\mathrm{t}}$ & $\mathrm{LDH}_{\hat{k}}$ & $\mathrm{LDH}_{5}$ & W. H. C. & T. M. & L. & $\mathrm{Im}$ \\
\hline $\mathrm{CPK}$ & & $0.717 * *$ & $0.593 * *$ & 0.057 & $0.820 * *$ & $-0.271 *$ & $0.299 *$ & 0.161 & -0.193 \\
\hline ALD & & & $0.546 * *$ & 0.088 & $0.717 * *$ & -0.216 & 0.176 & 0.206 & -0.136 \\
\hline $\mathrm{LDH}_{\mathfrak{k}}$ & & & & $0.540^{* *}$ & $0.469 * *$ & -0.218 & 0.172 & 0.198 & $-0.262^{*}$ \\
\hline $\mathrm{LDH}_{4}$ & & & & & 0.076 & 0.002 & 0.054 & 0.187 & -0.099 \\
\hline $\mathrm{LDH}_{5}$ & & & & & & $-0.345 * *$ & 0.191 & 0.177 & $-0.305^{*}$ \\
\hline W. H.C. & & & & & & & $-0.462^{* *}$ & $-0.587 * *$ & $0.836 * *$ \\
\hline T. M. & & & & & & & & $0.382^{* * *}$ & $-0.760 * *$ \\
\hline L. & & & & & & & & & $-0.809 * *$ \\
\hline
\end{tabular}

W.H.C.: Water holding capacity. T. M.: Toughness of meat. L.: Hunter's L value. Im: The meat character index. 
Watanabe, Akita, Nishoin, Ito, Nishida and Himeno

and the physical properties of meat, between Im and $\mathrm{LDH}_{t}$, and $\mathrm{LDH}_{5}$, a correlation coefficient of $-0.262^{*}$ and $-0.305^{*}$ was found, respectively. Also, between Im and water-holding capacity, toughness of meat and Hunter's $L$ value, a correlation coefficient of $0.836^{* *},-0.760 * \%$ and $-0.809 * *$ was recognized, respectively.

\section{Discussion}

To characterize the meat property in relation to PSE condition, it is necessary to measure pale, soft and exudative aspects, which can be done in various ways, subjectively as well as objectively ${ }^{36)}$. However, in a practical sense, the substantial contribution of water-holding capacity, toughness and Hunter's L value of meat to PSE condition has been demonstrated in the literatures $^{82,37-43)}$ and these physical properties have been playing useful roles in physio-genetic studies in combination with the subjective evaluation of meat ${ }^{5,26,28,82,41,48,44)}$. In the present study, to correlate the muscle cell enzyme activities in serum with the meat properies, only those physical properties of meat were investigated, because the subjective scoring system for PSE meat has not been established in Japan at the moment.

To describe the merit of meat property, an objective evaluation by standardized deviation $\left[(x-\bar{x}) / \sigma_{x}\right]$ from the population mean has been proposed by BLENDL ${ }^{43)}$ and $\mathrm{F}_{\text {LOCK }}{ }^{43)}$ for color brightness, and MÄDER et al. ${ }^{26)}$ for a meat character index consisting of $\mathrm{pH}_{1}$, color brightness and water-holding capacity. BLENDL and FLOCK showed that pigs with color brightness below $\bar{x}-\sigma$ would be PSE and pigs above $\bar{x}+\sigma$ would get maximum points for meat quality. When the present authors applied this concept to DAvrs et al.'s data ${ }^{99)}$, a fairly good agreement was recognized in there lationship between loin color score and $\mathrm{pH}_{1}$, Hunter's $\mathrm{L}$ value and water-holding capacity (percent free water) except only a slight disagreement in $x+\sigma$ value of water-holding capacity. This observation may support that the application of objective evaluation to the physical properties of meat in the present study will be meaningful.

Allen and Patterson ${ }^{12)}$ and Elizondo et al. ${ }^{29)}$ showed that large differences were observed among CPK activities assayed in blood taken from ear veins, anterior vena cava before death and exsanguination during slaughter. And they explained that increases in CPK activity might have been a genuine effect postmortem or it may have resulted from contamination of plasma with minute fragments of muscle tissues and the latter seemed more likely as increases were also observed when blood was taken from anterior vena cava. The present results suggest that the large and variable enzyme activity increases are avoided if the ear vein blood is used as the standard sample for CPK determination.

The present results of determination of the activities of the muscle cell enzymes in serum showed that the experimental pigs consisted of two types of animals concerning the enzyme activity. The major type was of apparently low activity of the enzymes and the minor was of extremely high activity, essentially corresponding with the results reported in the literatures s.7-10.12- $^{-12}$ 14,21-26,29-32). The individuals demonstrated to have extremely high values of the enzyme activity in the present study can be regarded as stress-susceptible and/or being prone to produce the meat of undesirable quality and the animals with apparently low enzyme activity can be regarded as a mixture of stress-resistant and latent stress-susceptible ones, judging from the physical properties of meat. The general premise here is that in stress-susceptible animals, the muscle cell enzymes leak into the blood because of changes in permeability of the cell membrane. Increased blood serum or plasma levels of such enzymes can therefore be used as diagnostic aids. 
The positive association between the extremely high muscle cell enzyme activities in serum and the incidence of the extremely disadvantageous Im values was suggested in the results shown in Figures 1 and 2, and Tables 2 and 3 as reported in the literatures, $5,9,11,18,11,20-22,26-30,32)$. As to the predictive role of the muscle cell enzyme activities in serum for the incidence of such Im values, the enzyme activities predicted three extremely disadvantageous Im values out of seven cases observed in the 61 animals. Also, the enzyme activities predicted five Im values below -1.00 out of 15 cases in the 61 pigs. The efficiency of prediction for the incidence of Im values below -3.00 was $3 / 10$ comparing to $7 / 61$ of the background incidence of such Im values. The efficiency of prediction for the incidence of Im values below -1.00 was $5 / 10$ comparing to $15 / 61$ of the background. The differences between the efficiencies of prediction and the background incidences were not statistically significant due to the limited number of observed animals. (In case In values below -1.00 the enzyme screening was significantly useful at $10 \%$ level of probability.) These results may suggest that the extremely high resting values of the activities of the muscle cell enzymes can be used only for a limited purpose as an indicator for detecting the incidence of the extremely disadvantageous physical property of meat and/or stress-susceptible animals being prone to produce PSE meat.

Statistically significant and high correlation coefficients among the activities of enzymn supposed to be playing a similar physiological role were found as a matter of course as shown in Table $4^{5,20}$. Also, significant and moderately high correlation coefficients recognized among the values of the physical properties of meat indicate the interdependence of the physical properties of meat ${ }^{5,36,37,39,45)}$. And significant and high correlation coefficients found between the physical properties and Im values imply that the usefulness of any single physical property employed in the present study to predict an overall aspect of the physical characteristics of meat On the other hand, among the activity values of the muscle cell enzymes in serum and the physical properties of meat, statistically significant but low correlation coefficients were found only between $\mathrm{CPK}$ and water-holding capacity, and toughness of meat, and between $\mathrm{LDH}_{5}$ and water-holding capacity ${ }^{5,22,25\rangle}$. No significant correlation coefficient was observed between the enzyme activity and Hunter's $\mathrm{L}$ value of meat. As to the relationship between the enzyme activities and the meat character index, significant but low correlation coefficients were found between $\mathrm{LDH}_{\mathrm{t}}$ and $\mathrm{LDH}_{5}$, and Im values, also.

The low correlation coefficients between the resting values of the enzyme activity and the physical properties of meat imply that these values are of less significance for predicting the meat quality of an individual animal because the enzyme determination of resting animals is in valid to detect the latent stress-susceptible animals, as shown in Table 3, which reveal their abnormality only under a designed stress condition ${ }^{5,8,13,15-20,23,26-32)}$ and furthermore all animals have to be subjected to peri-slaughter stress and effects of carcass handling after slaughtering which affect the meat quality and are very difficult to control experimentally, as suggested by EIKelenвoом et al.45) Therefore, more emphasis should be placed on relating the results of such determinations to the genetic predisposition of the animal rather than to the degree of postmortem meat quality ${ }^{2)}$. For this purpose correlation analysis in the present study suggests that a simultaneous use of CPK, $\mathrm{LDH}_{\mathrm{t}}$ and $\mathrm{LDH}_{5}$ would be reasonable.

Very recently, the autosomal recessive mode of inheritance of porcine stress-susceptibility defined in terms of malignant hyperthermia which is induced by halothane anesthesia has been re-

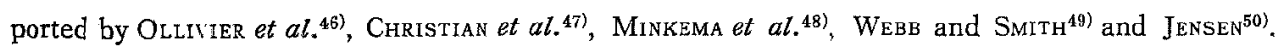
Since the same aspect of inheritance as above has been suggested in the present author's preli 
Watanabe, Akita, Nishojl, Ito, Nishida and Himeno

minary study ${ }^{52}$ in addition to a familial occurrence of the extreme muscle cell enzyme values and physical properties of meat observed in Table 3, halothane anesthesia devised by EIKELENBoom and MINKEMA $^{21)}$, and Christian ${ }^{51)}$ should be employed instead of a designed physical stress test for the further study of the screening.

The authors wish to express their gratitudes to Dr. S. Nishio for suggestions made in the preparation of the manuscript, and Mr. K. Mryama for technical assistance.

\section{References}

1) Sybesma, W., Proc. 3rd Int. Conf. Production Disease in Farm Animals, Wageningen, The Netherlands, Sept. 13-16, 1976. 137-140. Pudoc. Wageningen, The Netherlands. 1977.

2) Cassens, R.G., D. N. Marple and G. Eikelenboom, Advances in Food Research, 21: 71155. Academic Press. New York. 1975.

3) Topel, D. G., Festskrift til Prof. Dr. Dr. h.c. Hjalmar Clausen i anledning af 70 års dagen, 29, August 1975. 265-278. Det. Kgl. Danske Landhusholdningsselskab. Copenhagen, Denmark. 1975.

4) Fukazawa, T., Jap. J. Zootech. Sci., 46: 501-508. 1975. (In Japanese)

5) Steinhauf, D., J. H. Weniger und K.H. Hoppenbrock, Züchtungskunde, 41: 93-111. 1969.

6) Sybesma, W. and G. Eikelenboom, Tijdschrift voor Diergeneeskunde, 2: 155-160. 1969.

7) Hessed-De Heer, J. C. M., Anim. Prod., 11: 423-427. 1969.

8) Unshelm, J., H. Hagenmeister und J. Schröber, Z. Tierzüchtg. Züchtgsbiol., 85: 338-353. 1969.

9) Woolf, N., L. Hall, C. Thorne, M. Down and R. Walker, Brit. Med. J., 3: 386-387. 1970.

10) Allen, W. M., S. Berrett, J. D. J. Harding and D. S. P. Patterson, Vet. Rec., 87: 410-411. 1970.

11) Schmidt, G. R., L. L. Kastenschmidt, R. G. Cassens and E. J. Briskey, J. Anim. Sci., 31: 1168-1171. 1970.

12) Allen, W. M. and D.S.P. Patterson, Proc. 2nd Int. Symp. Condition and Meat Quality in Pigs, Zeist, The Netherlands, March 22-24, 1971. 90-96. Pudoc. Wageningen, The Netherlands. 1971.

13) Bickhardt, K., Proc. 2nd Int. Symp. Condition and Meat Quality in Pigs, Zeist, The Netherlands, March 22-24, 1971. 36-42. Pudoc. Wageningen, The Netherlands. 1971.

14) Mrrkel, R. A., Proc. 2nd Int. Symp. Condition and Meat Quality in Pigs, Zeist, The Netherlands, March 22-24, 1971. 97-103. Pudoc. Wageningen, The Netherlands. 1971.

15) Kallweit, E., S. Haase, J. H. Weniger and D. Steinhauf, Z. Tierzüchtg. Züchtgsbiol., 89: 159-169. 1972.

16) Haase, S., E. Kallweit, D. Stemnauf und J. H. Wenrger, Z. Tierzüchtg. Züchtgsbiol., 89: 217-234. 1972.

17) Haase, S., J. Petersen, D. Steinhauf und J.H. Weniger, Z. Tierzüchtg. Züchtgsbiol., 90: 180-185. 1973.

18) Steinhauf, D., S. Haase, J. Petersen und J. H. Weniger, Z. Tierzüchtg. Züchtgsbiol., 90: 186-191. 1973.

19) Richter, L., D. K. Flock und K. Bickhardt, Züchtungskunde, 45: 429-438. 1973. 
20). Adiss, P. B., D. A. Nelson, T-I Ma and J. R. Burroughs, J. Anim. Sci, 38: 279-286, 1974.

21) Eikelenboom, G. and D. Minkema, Tijdschrift voor Driergeneeskunde. 99: 421-426. 1974.

22) Schmidt, G. R., D.W. Crist and J. E. WAx, J. Anim. Sci., 38: 295-303. 1974.

23) Christian, L. L., CPK stress syndrome detection. A.S. 410F. 3pp. Cooperative Extension Service, Iowa State Univ. Agricultural and Home Economics Experiment Station. Ames, Iowa. 1975.

24) Beermann, D.H., D. N. Marple, C. W. Hirschinger and R. G. Cassens, J. Anim. Sci., 40 75-77. 1975.

25) Wax, J. E., H. W. Norton and G. R. Schmidt, J. Anim. Sci., 40: 444-450. 1975.

26) Mäder, H. P., E. Kallweit, J. H. Weniger und D. Steinhauf, Z. Tierzüchtg. Züchtgsbiol., 92: 127-132. 1975 .

27) Kallweit, E., H.P. Mäder, D. Steinhauf und J. H. Weniger, Z. Tierzüchtg. Züchtgsbiol, 92: 188-194. 1975,

28) Weniger, J. H., D. Steinhauf, H.P. Mäder und E. Kallweit, Z. Tierzüchtg. Züchtgsbiol, 92: 195-204. 1975.

29) Elizondo, G., P.B. Adiss, W. E. Rempel, C. Madero, F. B. Martin, D. B. Anderson and D. N. Marple, J. Anim. Sci,, 43: 1004-1014. 1976.

30) Allen, W. M., K. A. Collis, S. Berrett and J. C. Bell, Proc. 3rd Int. Conf. Production Disease in Farm Animals, Wageningen, The Netherlands, Sept. 13-16, 1976. 179-182. Pudoc. Wageningen, The Netherlands. 1977.

31) Lampo, Ph., Proc. 3rd Int. Conf. Production Disease in Farm Animals, Wageningen, The Netherlands, Sept. 13-16, 1976. 172-175. Pudoc. Wageningen, The Netherlands. 1977.

32) Lunow, J., Jucker, P. Schmidt and A. Schneider, Proc. 3rd Int. Conf. Production Disease in Farm Animals, Wageningen, The Netherlands, Sept. 13-16, 1976. 176-178. Pudoc. Wageningen, The Netherlands. 1977.

33) Ando, S., F. Saito, H. Nakai and T. Ikeda, Jap. J. Zootech. Sci., 41: Suppl. 70. 1970. (In Japanese)

34) IkedA, T., F. Saito and S. Ando, Bull. Nat. Inst. Anim. Ind., No. 18: 15-19. 1968. (In Japanese)

35) Ikeda, T., H. Nakai, F. Saito and S. Ando, Bull. Nat. Inst. Anim. Ind., No. 30: 53-58. 1976. (In Japanese)

36) Walstra, P., A. A. M. Jensen and G. Mateman, Proc. 3rd Int. Conf. Production Disease in Farm Animals, Wageningen, The Netherlands, Sept. 13-16, 1976. 197-199. Pudoc. Wageningen, The Netherlands. 1977.

37) Herring, H. K., J. H. Haggard and L. H. Hansen, J. Anim. Sci,, 33: 578-586. 1971.

38) Schepper, J., Proc. 2nd Int. Symp. Condition and Meat Quality in Pigs, Zeist, The Netherlands, March 22-24, 1971. 271-277. Pudoc. Wageningen, The Netherlands. 1971.

39) Davis, C.E., W.E. Townsend, H. C. Maccampell and A. J. Mercuri, J. Anim. Sci., 38: 746$751,1974$.

40) Buchter, L and P. Zeutphen, Proc. 2nd Int. Symp. Condition and Meat Quality in Pigs, Zeist, The Netherlands, March 22-24, 1971. 247-254. Pudoc. Wageningen, The Netherlands. 1971.

41) Dildey, D. D., E. D. Aberle, J. C. Forrest and M. D. Judge, J. Anim. Sci., 31: 681-685. 1970.

42) Sayre, R. N., B. Kiernat and E. J. Briskey, J. Food Sci., 29: 175-181. 1964.

43) Blendl, H. M., Züchtungskunde, 38: 234-246. 1966.

44) FLock, D., Die Fleischwirtschaft, 48: 1362-1365. 1968. 


\title{
W atamabe, Akita, Nishojt, Iro, Nishida and Himeno
}

45) Eikelenboom, G., D. R. Campion, R. G. Kauffman and R. G. Cassens, J. Anim. Sci., 39: 303-308. 1974.

46) Ollivier, L., P. Sellier et G. Monin, Ann. Génét. Sél. Anim., 7: 159-166. 1975.

47) Christian, L. L., D. L. Kuhlers and D. G. Topel, Genetic improvement in the production of quality pork. Iowa NC-103. $12 \mathrm{pp}$. Annual Report 1975-1976. Iowa State University. Ames, Iowa. 1976.

48) Minkema, D., G. Erkeleneoom and P. Van Eldik, Proc. 3rd Int. Conf. Production Disease in Farm Animals, Wageningen, The Netherlands, Sept. 13-16, 1976. 203-205. Pudoc. Wageningen, The Netherlands. 1977.

49) Webb, A. J. and C. Smith, Proc. 3rd Int. Conf. Production Disease in Farm Animals, Wageningen, The Netherlands, Sept. 13-16, 1976. 211-213. Pudoc. Wageningen, The Netherlands. 1977.

50) Jensen, P., Personal communication. 1977.

51) Christian, L. L., Halothane test for PSS-field application. Proc. Am. Ass. Swine Practitioners Conf. 6 pp. Des Moines, Iowa. 1974.

52) Watanabe, S., Proc. 1st Nat. Symp. Malignant Hyperthermia, Hiroshima, Japan. Oct. 25, 1977. (In press)

\section{日本のランドレース豚における血清中の骨格筋由来 醭素活性之肉の物性值乞の関係}

\author{
渡辺昭三・秋田富土・仁昌寺 博* ・伊藤 菁* ・ \\ 西田 朗*・姫野健太郎 \\ 農林省畜産試験場, 千葉市 280 \\ *岩手県畜産試験場，岩手県滝沢村 020-01
}

\begin{abstract}
産肉能力検定中のランドレース 76 頭を供試して，安 静時における血清中のタレフチン・ホスホキナーゼ (CPK)，アルドラーゼ(ALD) おょび乳酸脱水素蟀素 $\left(\mathrm{LDH}_{\mathrm{t}}\right)$ の活性と乳酸脱水素醉䛶のアイソザイムパター ンを調査した. 血清中の醉素測定のためには日龄139.7 10.5 で耳静脈汃ら採血し，午のうち61 頭は屠体形質上 肉の物性測定值調査のため，体重が $90 \mathrm{~kg}$ に達したとき 屠殺した，屠殺時の日業领は $150.8 \pm 10.2$ であった，極端 に高い CPK, ALD, $\mathrm{LDH}_{\mathrm{t}}$ 活性之極端飞高い $\mathrm{LDH}_{5} \mathrm{~T}$ インザイムの比率を示すものが 61 頚中に 10 頭認められ た。肉の保水力と硬さ㧍よびハンターのL 值が不利な值
\end{abstract}

をつ個体は，血清醉素が正常な群よりる，同酵素が極端 な值をもつ群に多く認められた，CPK 活性および $\mathrm{LDH}_{5}$ の比率之肉の保水力および硬さとの間には，統計的に有 意ではあるが低い相関しかないことが再確認された。 ま た, $\mathrm{LDH}_{\mathrm{t}}$ 㧍よび $\mathrm{LDH}_{5}$ 之前記 3 物性值の変異を標準化 して構成した“肉の特性指数”との間にあ有意ではあ るが低い相関が認められた。不利な物性値を示寸肉にな りやすいストレス感受性豚を検出するための，安静洔の 血清中骨格筋由来醉素活性測定の機能々限界について溚 祭した. 